\title{
MODELING OF THE HYDRAULIC PERFORMANCE OF OGEE SPILLWAY USING COMPUTATIONAL FLUID DYNAMICS (CFD)
}

\author{
DR. Jowhar R. Mohammed ", DR. BahZad M. A. Noori ${ }^{* *}$ and IhSAN A. HuSSEIN *** \\ * College of Engineering; University of Duhok, Kurdistan Region-Iraq \\ ** Dept. of Civil Engineering, University of Duhok, Kurdistan Region-Iraq \\ ***. Water Resources Engineering, Private Sector, Kurdistan Region-Iraq
}

\begin{abstract}
Computational fluid dynamics (CFD) is a type of numerical modeling that is used to solve problems involving fluid flow. Since CFD can provide faster and more economical solution than physical modeling, hydraulic engineers are interested in verifying the capability of CFD software. This study has examined the ability of the commercial CFD software (Flow-3D) to model an ogee-crested spillway by making data comparisons to physical models (experimental data). Three spillway models of different heights $(20 \mathrm{~cm}, 25 \mathrm{~cm}$, and $30 \mathrm{~cm})$ were fabricated and tested for design heads of $(5 \mathrm{~cm}, 7 \mathrm{~cm}, 10 \mathrm{~cm})$, respectively. The study was conducted to compare flow parameters over a standard ogee-crested spillway using physical and numerical models. The physical models were fabricated from a rigid foam and placed in a test flume. Pressure taps were installed along the entire length of the spillways. Water surface profiles and pressure data were recorded for five different flow conditions $(1.2 \mathrm{Hd}, 1 \mathrm{Hd}, 0.75 \mathrm{Hd}, 0.5 \mathrm{Hd}$, and $0.25 \mathrm{Hd})$. The results of this study showed that there were good agreements between the results of physical and numerical models for water surface profiles and there were some discrepancies in pressure results.
\end{abstract}

KEY WORDS: Ogee Spillway, Modeling, CFD, Surface Profiles, Pressure Measurements.

\section{INTRODUCTION}

$\mathbf{T}$ The most common type of spillways is the ogee-crested spillway that widely used all over the world due to its ability to pass flow efficiently and safely when properly designed and constructed. The performance characteristics of ogee-crested spillways are due to its shape being derived from the lower surface of an aerated nappe flowing over a sharp-crested weir. The ogee shape results in near-atmospheric pressure over the crest section for a design head. If the head is lower than the design head, the discharge is less because of the crest resistance. However, at higher heads, the discharge is greater than an aerated sharp-crested weir because the negative crest pressure suctions more flow. The analysis of water flow over a spillway is an important engineering problem using the empirical information and physical model studies. The use of physical models can be very costly, time consuming, has error due to scale, and has limitations to take various options throughout the design process.

Presently hydraulic engineering relies heavily on physical models for the design of spillways and most hydraulic structures. With the advances in numerical methods and computing power, computational models of spillway flows are increasingly being used in industry but still require validation by a physical model to ensure that the virtual modeling of physical processes is accurate. The consequences of the failure of large hydroelectric dam on downstream sections of a river reach most importantly on human life can be catastrophic.

Several computational approaches have been developed including modeling in one, two or three dimensions which use a wide variety of equations and discretization techniques. In the present study, a numerical model using computational fluid dynamic (CFD, Flow-3D) was developed. Different ogee-crested spillway models were fabricated and tested experimentally to obtain water surface profiles and pressure measurements along the spillway surface. The experimental results of water surface profile and pressure distribution were compared with those obtained from numerical models to see to what extent they agree with each other. 


\section{LITERATURE REVIEW}

In the last decade, several hydraulic engineers have attempted to analyze the flow over ogeecrested spillways with a variety of mathematical models and computational methods. Because of advances in computational power, numerical modeling coupled with physical measurements are currently providing insight to understand the intricacies of flow over spillways. Many investigators indicated that there are gaps in knowledge and design of ogee-crested spillway and they tried to implement some numerical and experimental techniques for solving the flow over this type of spillways. Guo et al. (1998) derive a non-singular boundary integral equation to model spillway with initially unknown discharge. A synchronous iterative method was then applied to determine the discharge and profile of flow. Good agreement was found between the results of their numerical model compared to those obtained from a physical model. Olsen and Kjellesvig (1998) developed the two dimensional work of Kjellesvig (1996) and used Reynolds Averaged NavierStokes (RANS) equations combined with the turbulence kinetic energy and dissipation rate model of Launder et al. (1972) to predict the discharge coefficient of ogee-crested overflow spillway. The results of the simulations indicated that the numerical model was in a good agreement with the physical one. Song and Zhou (1999) used a large simulation with an explicit finite volume scheme to determine the free surface flow over ogee-crested overflow spillway. The location of the free surface was computed using the marker and cell method of Harlow and Welsh (1965) while a free steepness limiting approach was used to model the free surface waves. Neglecting air entrainment, the results of the three dimensional model showed good agreement with those of the physical model at the entrance while neglecting air entrainment tended to predict smaller water levels further downstream. Savage and Johnson (2001) used the computational fluid dynamics (CFD) software package (Flow-3D) for their numerical model. The results of the numerical model showed one percent error compared to those measured from physical model for discharge measurements when the ratio of upstream effective head over crest to design head greater than 0.7. Ho and Donohoo (2001) compared their numerical model results (based on flow-3D) with data computed by Water ways Experimental Station (WES) equations. The comparison showed that the computed results overestimated the velocity and underestimated the pressure distribution along the spillway. Later, Ho et al. (2003) made comparisons of crest pressures and discharges over a standard ogee-crested spillway from two and three dimensional simulations (CFD, Flow3D) with USACE-WES data and empirical discharge equations finding that CFD results predicted slightly higher negative pressures. Also, the comparison showed that the two dimensional simulation overestimated flow rates by 10 to 20 percent depending on the elevation of water head. The free surface profile of water over regular ogee-crested spillways was also studied by Chatila and Tabbara (2004) through a numerical model using CFD of ADINA software showing good agreement between the computed and measured profiles at crest and toe portions of the spillway. In their study, physical models of different scales were used for the comparison demonstrating the ability of CFD models to replace physical model results. Gessler (2005) documented how Flow-3D can be used to model a discharge over a spillway with probable maximum flood levels showing good agreement with previous physical model studies. A document reviewing of the application of Flow-3D to eight spillway upgrade projects in Australia was presented by $\mathrm{Ho}$ et al. (2006) finding that the numerical model flow rates were obtained with five percent overestimation compared to physical model results. They concluded that CFD is a viable technology for use in design and rehabilitation of spillways. Another study on ogee-crested spillways was conducted by Johnson and Savage (2006) taking into consideration the effect of tail water by testing different physical models varying in shape and dimensions in the numerical model. The Flow-3D software was used to solve RANS equations by finite volume method. The comparison showed that the difference between measured and computed discharges was running between $0.45 \%$ and $1.7 \%$ for different models. Maximum relative error in pressure was $7.8 \%$ between numerical simulation results and those of physical model. A hydrodynamic modeling of flow over spillway using two-dimensional finite volume-based numerical model was presented by Bhajantri et al. (2006) and compared their numerical model results with those of ogee-crested spillway of Omkareshwar dam constructed on the river Narmada in Madhya Pradesh in India as a physical 
model. The results showed that the computed and experimental values of discharge coefficient were 0.72 and 0.69 , respectively with a $4 \%$ difference. An improvement of hydraulic stability of spillways using CFD model was constructed by Kim et al. (2010) and they compared their numerical results with those of Karian dam in Indosia(as a physical model). The simulation results showed that the flow in the spillway was stable and excellent agreement was found between the hydraulic model test results and those of numerical simulation. Irzooki et al. (2016) studied experimentally the energy dissipation and pressure distribution over stepped spillways via testing four physical models of different heights and various step numbers. They compared their results with those obtained from a numerical model using computational fluid dynamics (CFD, Flow-3D). The maximum relative range of error in energy dissipation results was between -2 to $11 \%$ obtained from the comparison between numerical results and those measured from the physical models for all cases of energy dissipation studied.

Many approaches for the modeling of spillway flow currently exist, the selection of any depends on the level of the details which the investigator wishes to obtain. From a practical view point, three dimensional modeling is the most important as engineers designing these structures require an increased level of details so as to ensure the stability and safety of ogee spillways.

\section{EXPERIMENTAL WORK}

\subsection{Physical Model}

Depending on the WES- standard spillway shape, three vertical face type models were designed having different spillway heights (P) equal to $20 \mathrm{~cm}, 25 \mathrm{~cm}$ and $30 \mathrm{~cm}$ with design heads $\left(\mathrm{H}_{\mathrm{d}}\right)$ equal to $5 \mathrm{~cm}, 7 \mathrm{~cm}$ and $10 \mathrm{~cm}$, respectively. The equation used for the design of downstream crest profile was (USACE - WES (1952)):

$$
\mathrm{Y}=\frac{X^{1.85}}{2 H_{d}^{0.85}}
$$

In which, $\mathrm{H}_{\mathrm{d}}$ is the design head above crest, $\mathrm{X}$ and $\mathrm{Y}$ are coordinates of crest profile with their origin at the highest point of the crest.

The downstream slope of the spillway face was taken as $0.8 \mathrm{H}: 1 \mathrm{~V}$ and the radius of curvature at toe was decided to be $10 \mathrm{~cm}$ for all models according to Khatsuria (2005) not to be less than three times the water depth at toe of the spillway. Details of the first spillway model are shown in Fig. (1). The discharge for the three spillway models were $7.37 \mathrm{l} / \mathrm{s}, 12.21 \mathrm{l} / \mathrm{s}$ and $20.85 \mathrm{l} / \mathrm{s}$. The design details of the three spillway models are shown in Table (1).

All models were fabricated from rigid foam and fourteen pressure tapings along the centerline of surface profile were fixed in order to measure the pressure. These taps were connected to vertical piezometers board and a high quality smooth paint was used to paint the spillway surface. Each model was tested by allowing different water heads to overtop the spillway. The ratios of applied head $(\mathrm{H})$ to design head $\left(\mathrm{H}_{\mathrm{d}}\right)$ were taken as $(1.2,1,0.75,0.5$, and 0.25$)$ for runs overtopping model one of design head $\left(\mathrm{H}_{\mathrm{d}}=5 \mathrm{~cm}\right)$ and model height $(\mathrm{P}=20 \mathrm{~cm})$. The ratios of $\left(\mathrm{H} / \mathrm{H}_{\mathrm{d}}\right)$ were taken as $(1.2,1,0.75,0.5$ and 0.25$)$ for runs overtopping model two of design head $\left(\mathrm{H}_{\mathrm{d}}=7 \mathrm{~cm}\right)$ and model height $(\mathrm{P}=25 \mathrm{~cm})$. Finally, the ratios of $\left(\mathrm{H} / \mathrm{H}_{\mathrm{d}}\right)$ were taken as $(1.2,1,0.75,0.5$ and 0.25$)$ for runs overtopping model three of design head $\left(\mathrm{H}_{\mathrm{d}}=10 \mathrm{~cm}\right)$ and model height $(\mathrm{P}=30 \mathrm{~cm})$. The applied heads for all models were measured at a location two and half times the maximum applied head upstream the vertical face using a point gauge of $0.1 \mathrm{~mm}$ accuracy.

The water surface profile was measured through two point gauges of accuracy $0.1 \mathrm{~mm}$ along the center line of each model to minimize the side wall effect. Water surface profile measurements started at a suitable location upstream the vertical face and ended up with the tail water depth downstream taking flume bed as a datum for all water surface measurements. 


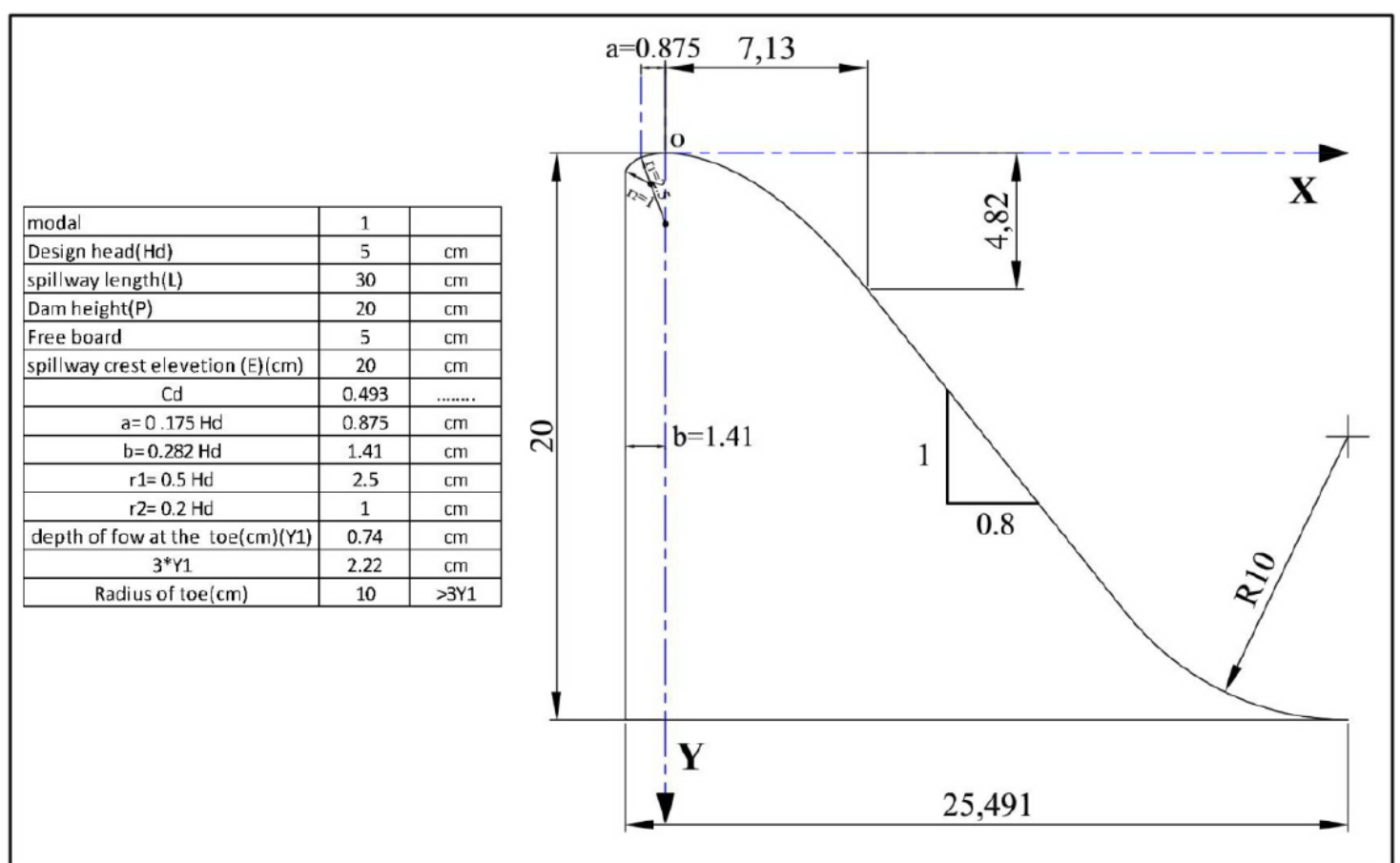

Fig. (1):- Details of the first spillway model (all dimensions are in centimeters).

Table (1):- Details of spillway models.

\begin{tabular}{|c|c|c|c|c|c|c|c|c|c|}
\hline $\begin{array}{c}\text { Model } \\
\text { No. }\end{array}$ & $\mathrm{P}$ & $\mathrm{H}_{\mathrm{d}}$ & $\mathrm{cm})$ & $\mathrm{a}$ & $\mathrm{b}$ & $\mathrm{r}_{1}$ & $\mathrm{r}_{2}$ & $\mathrm{R}_{\mathrm{t}}$ & $\begin{array}{c}\text { Design } \\
(\mathrm{cm})\end{array}$ \\
\hline 1 & 20 & 5 & 0.493 & 0.875 & 1.41 & 2.5 & 1 & 10 & 7.37 \\
\hline 2 & 25 & 7 & 0.493 & 1.225 & 1.974 & 3.5 & 1.4 & 10 & 12.21 \\
\hline 3 & 30 & 10 & 0.493 & 1.75 & 2.82 & 5 & 2 & 10 & 20.85 \\
\hline
\end{tabular}

Notation a, b, r1, r2 and R are defined in Fig. (1).

\subsection{Numerical Modeling}

In the present study, the (CDF, Flow-3D) model included 3D symmetrical representation of the existing spillway. This package is a finite difference / volume, free surface, unsteady flow modeling system developed to solve the NavierStokes equations in three dimensions. The software includes several turbulence algorithms that allow for solving RANS equations and the $\mathrm{k}$ $-\epsilon$ and RNG closure models.

Numerical model geometry was prepared by drawing spillway models using AutoCAD in 3D form and exported into Stereo Lithography (STL) format then directly imported into Flow-3D where the appropriate mesh generated.

Simulations were generally completed using the explicit solver options. Most simulations were run with automatic button selected. After the readiness of each model, the model will start simulating and this process takes long time depending on mesh size, initial conditions and finish time and finally the results will output for water surface profiles and pressures. 


\section{RESULTS AND DISCUSSION}

4.1 Water Surface Profiles

Water surface profiles obtained from the numerical and physical models are plotted in Figs (2-a) to $(2 \mathrm{e})$ for the ratios of $\left(\mathrm{H} / \mathrm{H}_{\mathrm{d}}\right)$ of $(1.2,1$, $0.75,0.5$ and 0.25$)$. The very close profiles show that there is a quite good agreement between the measured and computed surface profiles especially at the crest region. Little discrepancies prevail at the downstream region of the spillway which may be attributed to not accounting air entrainment in the numerical model. The differences between measured and computed results do not exceed $5 \%$ for all ratios of $\left(\mathrm{H} / \mathrm{H}_{\mathrm{d}}\right)$. Similar comparisons for models two and three are shown in Figs (3-a) to (4-e). These figures illustrate that quite good agreements are obtained with a maximum discrepancy between measured and computed water surface profile results of $7 \%$ for model two and $3 \%$ for model three for most extreme cases at the toe region.

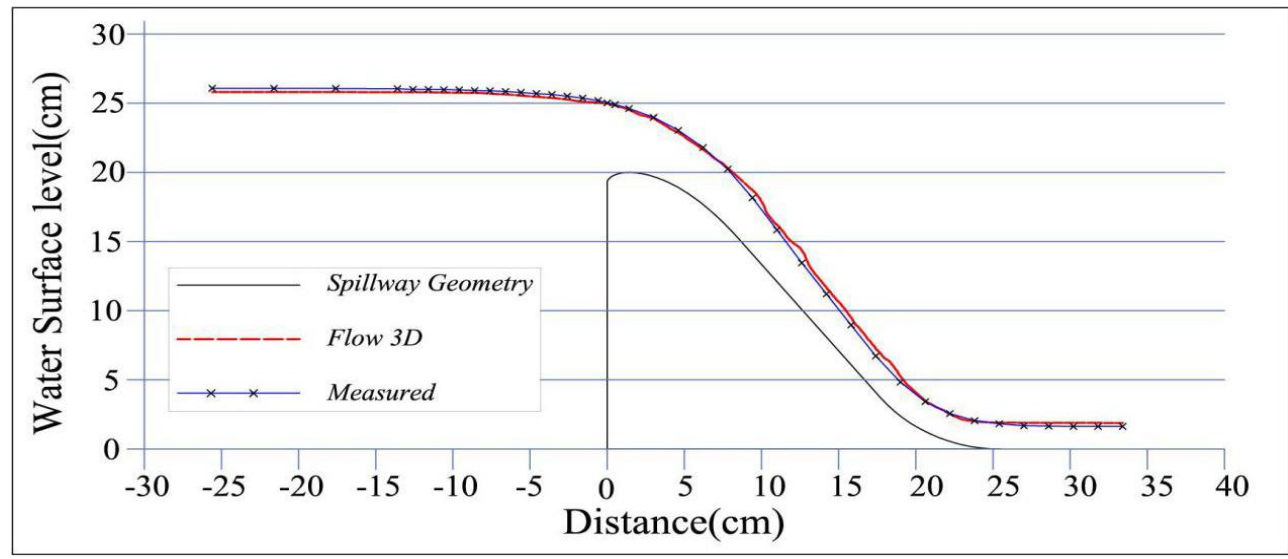

Fig. (2-a): Comparison between measured and computed water surface profiles for model (1) $\left(P=20 \mathrm{~cm}, H_{d}=5 \mathrm{~cm}\right.$ and $\mathrm{H} / \mathrm{H}_{\mathrm{d}}=1.2$ ).

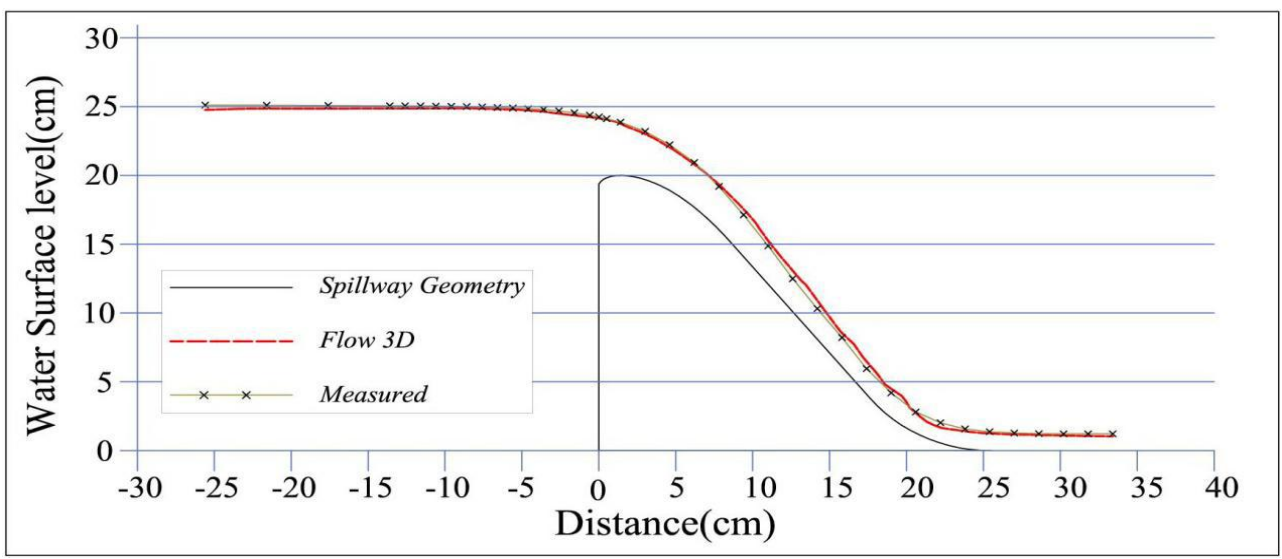

Fig. (2-b): Comparison between measured and computed water surface profiles for model (1) ( $P=20 \mathrm{~cm}, \mathrm{H}_{\mathrm{d}}=5 \mathrm{~cm}$ and $\mathrm{H} / \mathrm{H}_{\mathrm{d}}=1.0$ ). 


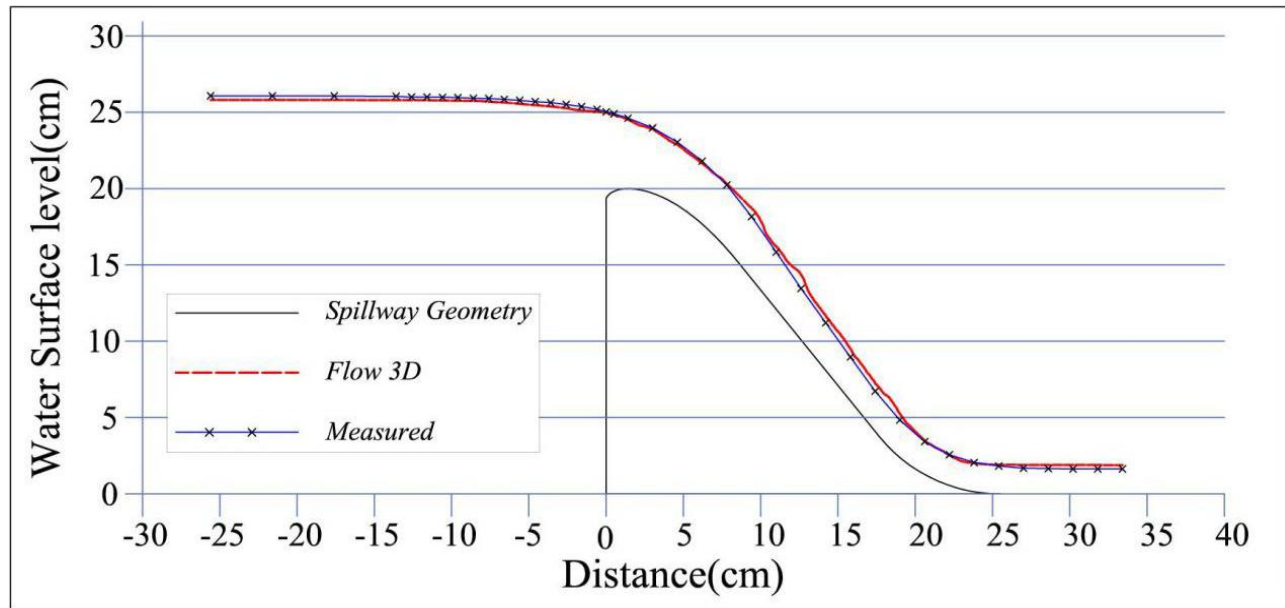

Fig. (2-c): Comparison between measured and computed water surface profiles for model (1) $\left(P=20 \mathrm{~cm}, \mathrm{H}_{\mathrm{d}}=5 \mathrm{~cm}\right.$ and $\left.\mathrm{H} / \mathrm{H}_{\mathrm{d}}=0.75\right)$.

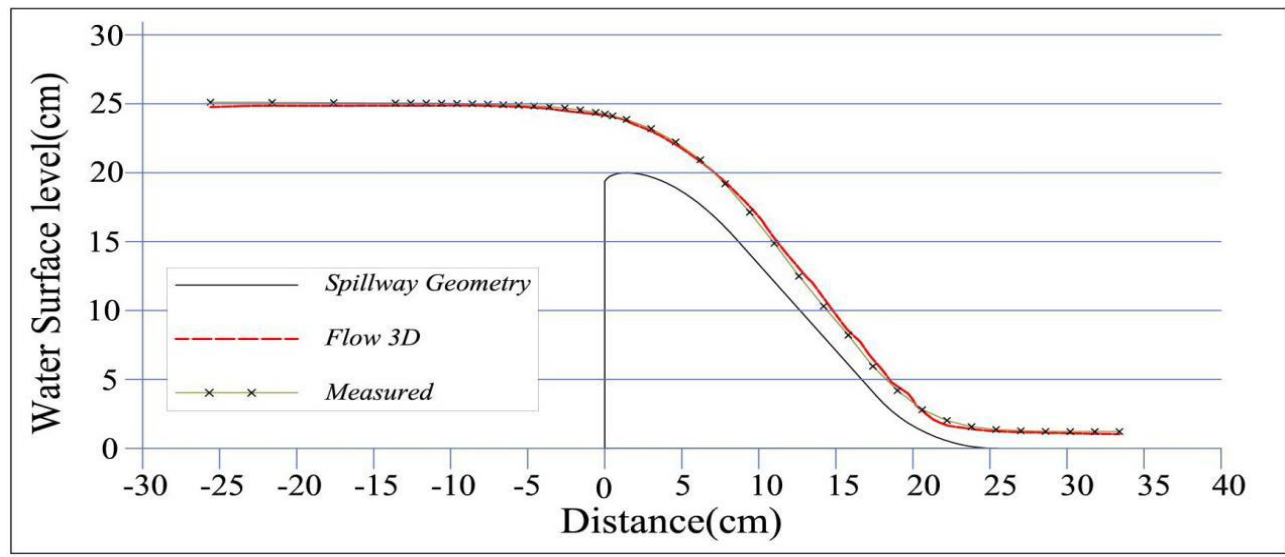

Fig. (2-d): Comparison between measured and computed water surface profiles for model (1) $\left(P=20 \mathrm{~cm}, \mathrm{H}_{d}=5 \mathrm{~cm}\right.$ and $\left.\mathrm{H} / \mathrm{H}_{\mathrm{d}}=0.5\right)$.

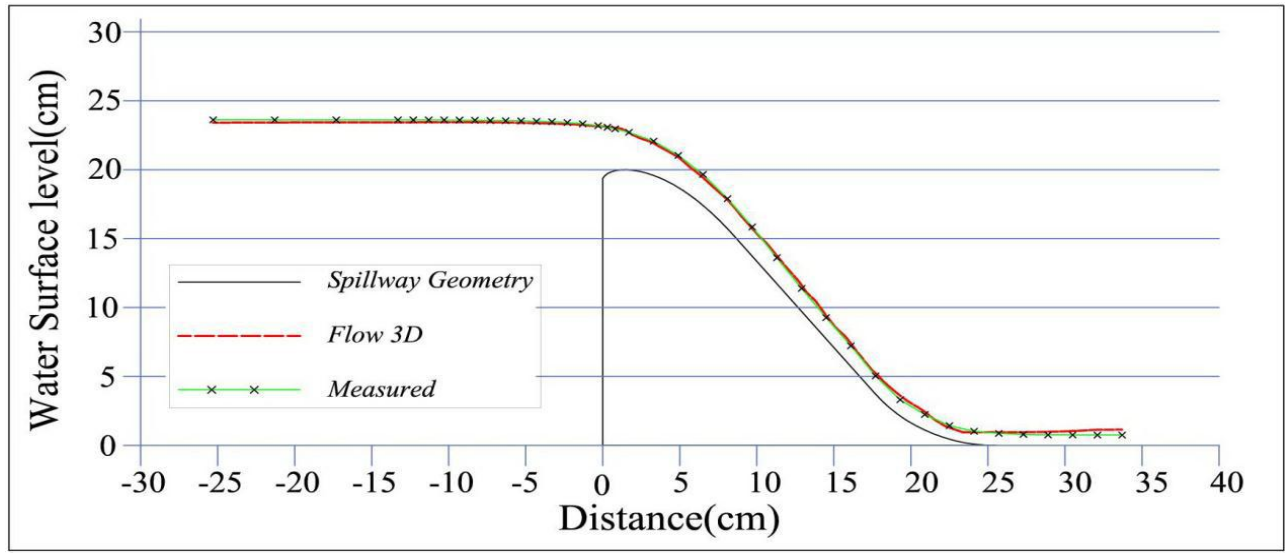

Fig. (2-e): Comparison between measured and computed water surface profiles for model (1) $\left(\mathrm{P}=20 \mathrm{~cm}, \mathrm{H}_{\mathrm{d}}=5 \mathrm{~cm}\right.$ and $\left.\mathrm{H} / \mathrm{H}_{\mathrm{d}}=0.25\right)$.

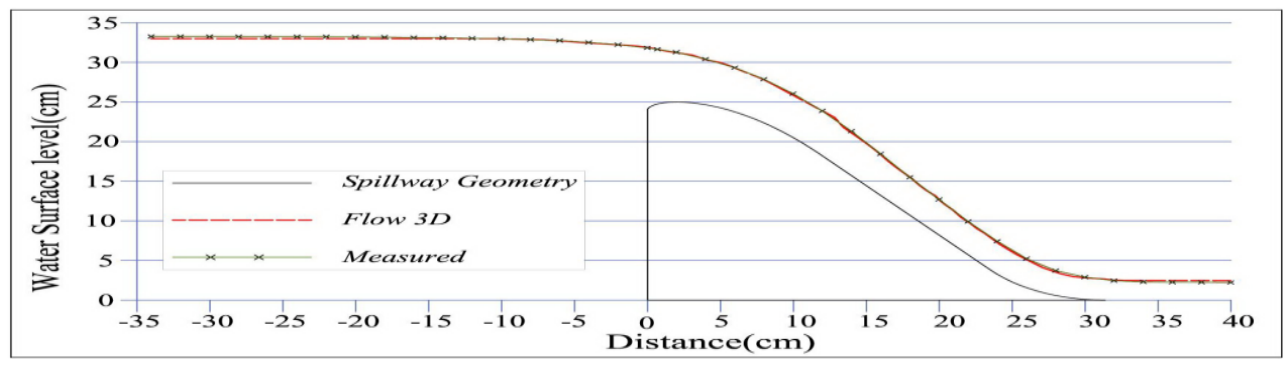


Fig. (3-a): Comparison between measured and computed water surface profiles for model (2) $\left(P=25 \mathrm{~cm}, \mathrm{H}_{d}=7 \mathrm{~cm}\right.$ and $\mathrm{H} / \mathrm{H}_{\mathrm{d}}=1.2$ ).

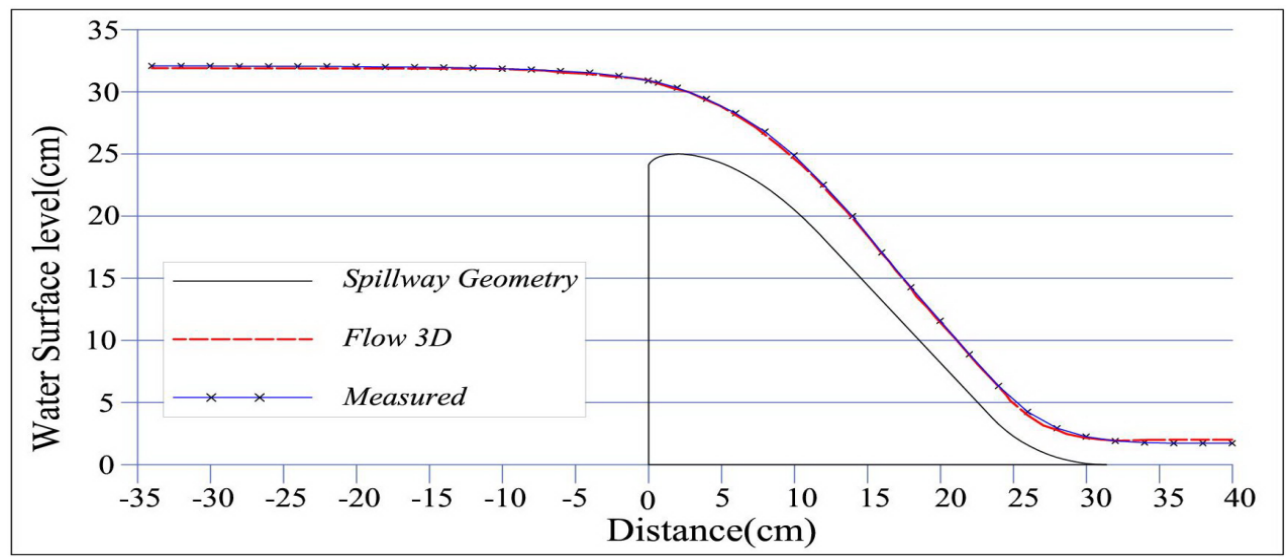

Fig. (3-b): Comparison between measured and computed water surface profiles for model (2) $\left(P=25 \mathrm{~cm}, \mathrm{H}_{d}=7 \mathrm{~cm}\right.$ and $\left.\mathrm{H} / \mathrm{H}_{\mathrm{d}}=1.0\right)$.

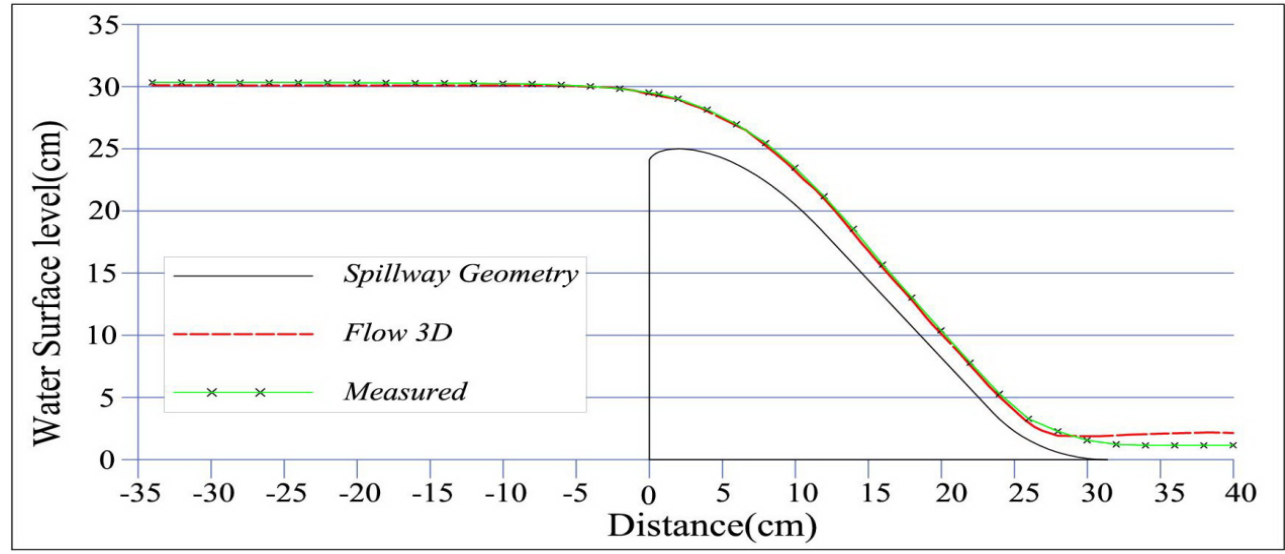

Fig. (3-c): Comparison between measured and computed water surface profiles for model (2) $\left(\mathrm{P}=25 \mathrm{~cm}, \mathrm{H}_{\mathrm{d}}=7 \mathrm{~cm}\right.$ and $\mathrm{H} / \mathrm{H}_{\mathrm{d}}=0.75$ ). 


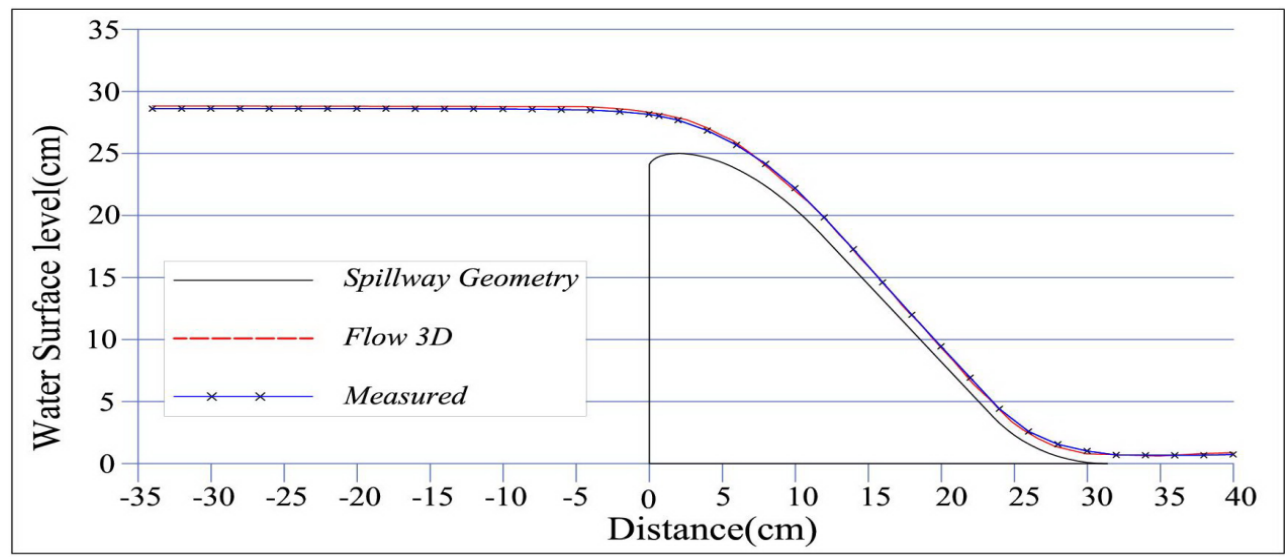

Fig. (3-d): Comparison between measured and computed water surface profiles for model (2) $\left(\mathrm{P}=25 \mathrm{~cm}, \mathrm{H}_{\mathrm{d}}=7 \mathrm{~cm}\right.$ and $\left.\mathrm{H} / \mathrm{H}_{\mathrm{d}}=0.5\right)$.

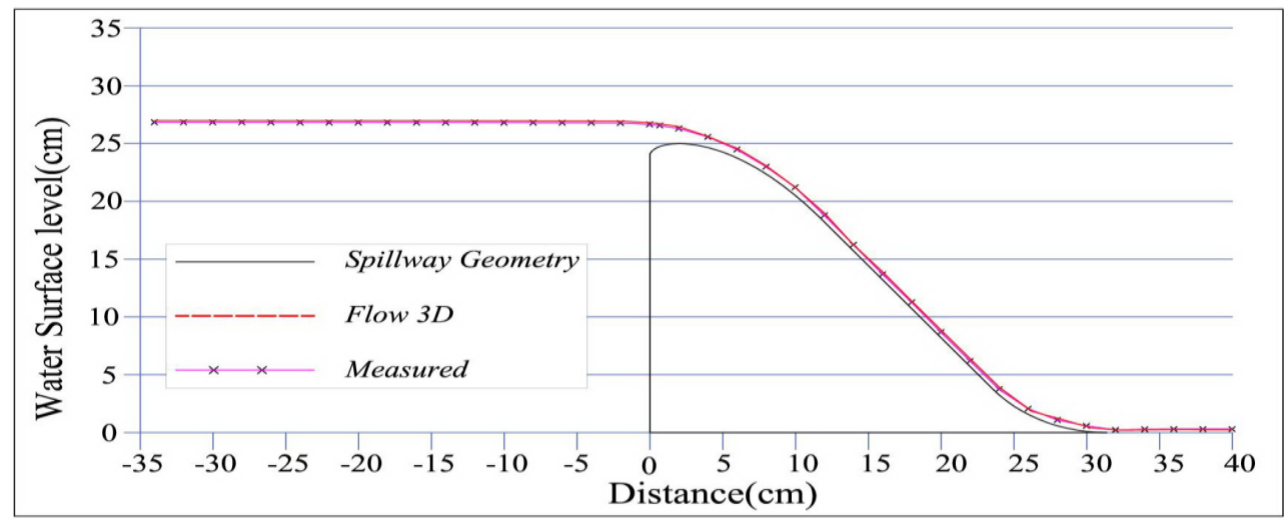

Fig. (3-e): Comparison between measured and computed water surface profiles for model (2) $\left(\mathrm{P}=25 \mathrm{~cm}, \mathrm{H}_{\mathrm{d}}=7 \mathrm{~cm}\right.$ and $\left.\mathrm{H} / \mathrm{H}_{\mathrm{d}}=0.25\right)$.

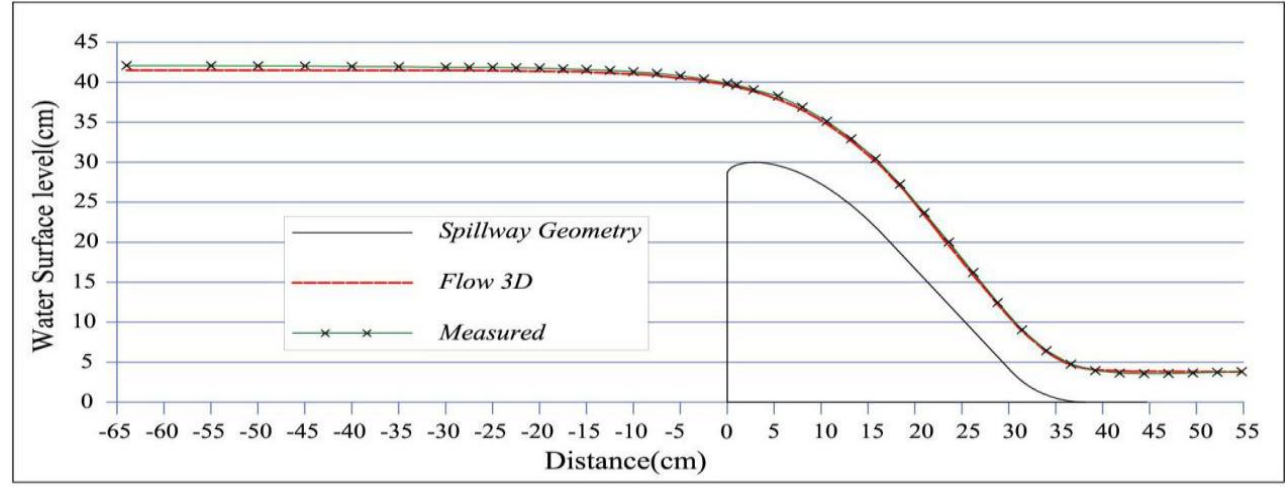

Fig. (4-a): Comparison between measured and computed water surface profiles for model (3) $\left(P=30 \mathrm{~cm}, H_{d}=10\right.$ $\mathrm{cm}$ and $\mathrm{H} / \mathrm{H}_{\mathrm{d}}=1.2$ ). 


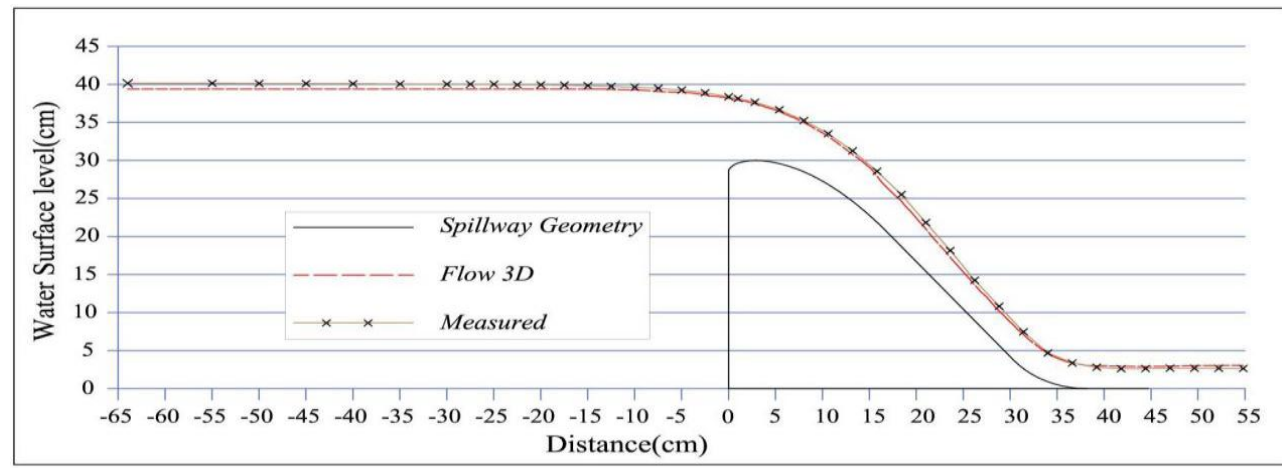

Fig. (4-b): Comparison between measured and computed water surface profiles for model (3) $\left(\mathrm{P}=30 \mathrm{~cm}, \mathrm{H}_{\mathrm{d}}=10\right.$ $\mathrm{cm}$ and $\mathrm{H} / \mathrm{H}_{\mathrm{d}}=1.0$ ).

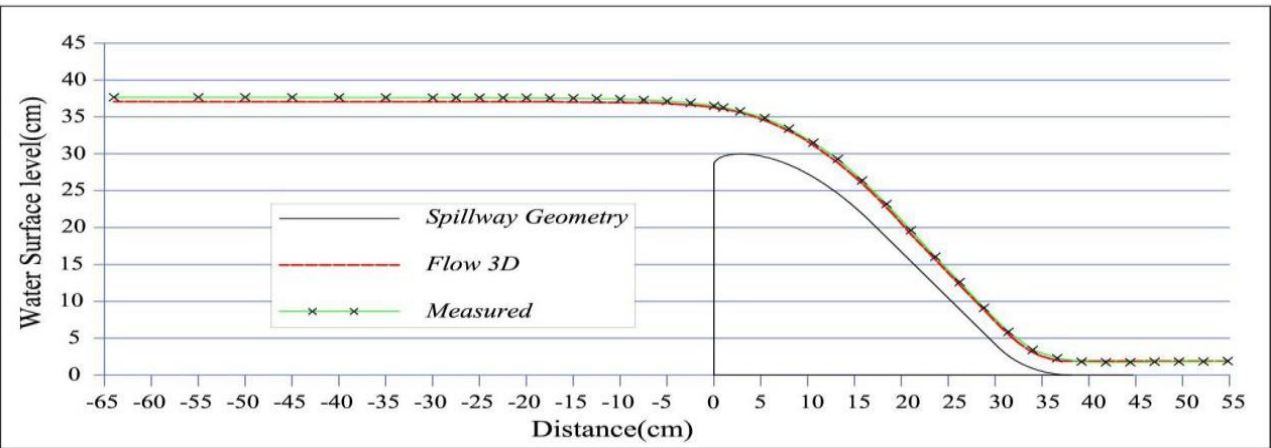

Fig. (4-c): Comparison between measured and computed water surface profiles for model (3) $\left(P=30 \mathrm{~cm}, \mathrm{H}_{d}=10\right.$ $\mathrm{cm}$ and $\left.\mathrm{H} / \mathrm{H}_{\mathrm{d}}=0.75\right)$.

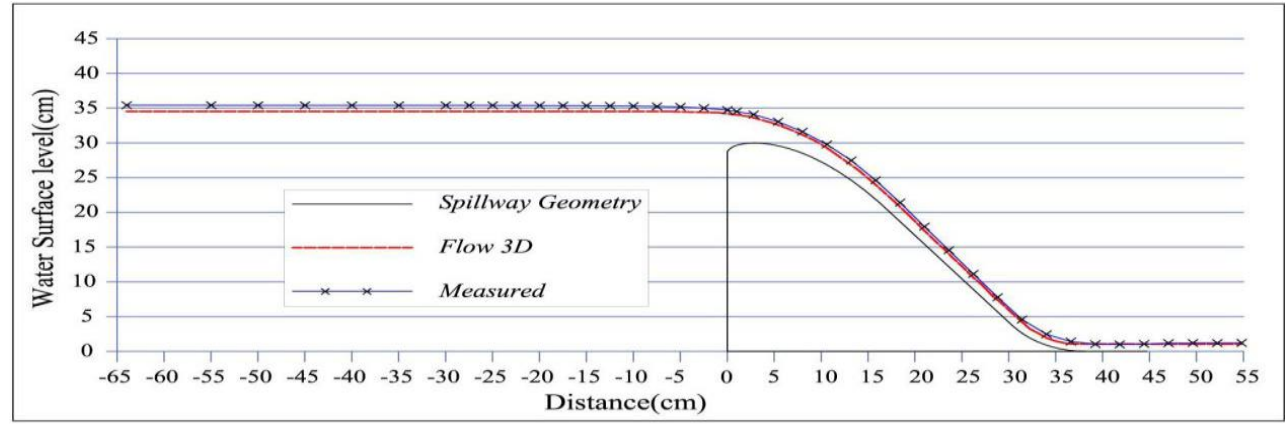

Fig. (4-d): Comparison between measured and computed water surface profiles for model (3) $\left(\mathrm{P}=30 \mathrm{~cm}, \mathrm{H}_{\mathrm{d}}=10\right.$ $\mathrm{cm}$ and $\mathrm{H} /$

$0.5)$.

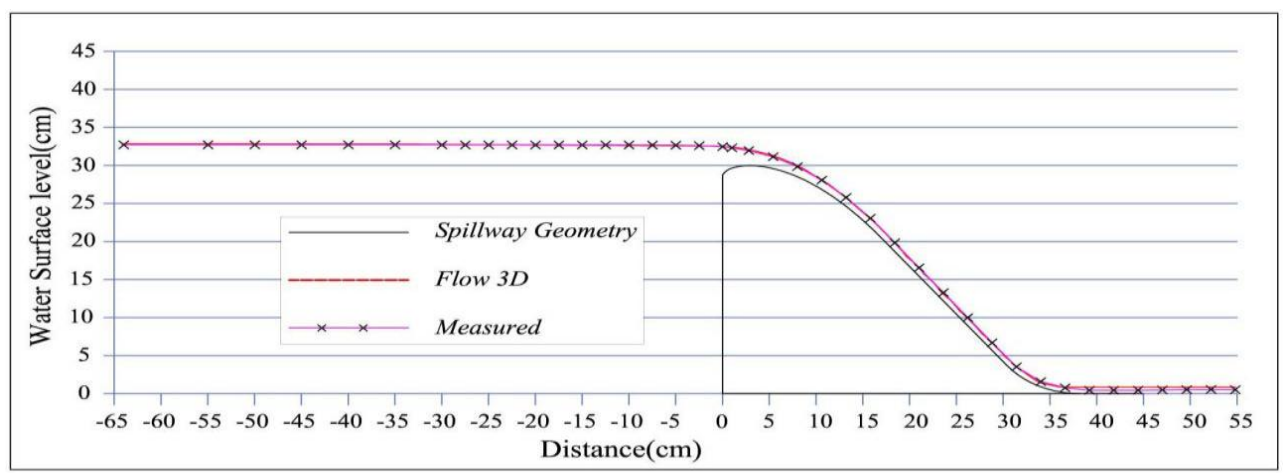

$\mathrm{H}_{\mathrm{d}}=$

Fig (4-e): Comparison between measured and computed water surface profiles for model (3) $\left(\mathrm{P}=30 \mathrm{~cm}\right.$ and $\mathrm{H}_{\mathrm{d}}=$ $10 \mathrm{~cm}$ and $\left.\mathrm{H} / \mathrm{H}_{\mathrm{d}}=0.25\right)$. 


\subsection{Pressure Results}

The pressure distributions along the center line of the spillway surface obtained from model one and those computed from the numerical model are plotted in Figs (5-a) to (5-e) for $\left(\mathrm{H} / \mathrm{H}_{\mathrm{d}}\right)$ ratios $(1.2$, $1,0.75,0.5$ and 0.25$)$. These figures show that there are some discrepancies between measured and computed results especially at the regions of crest and toe. The differences at the region of crest are attribute $\mathrm{d}$ to the waves of the upstrea

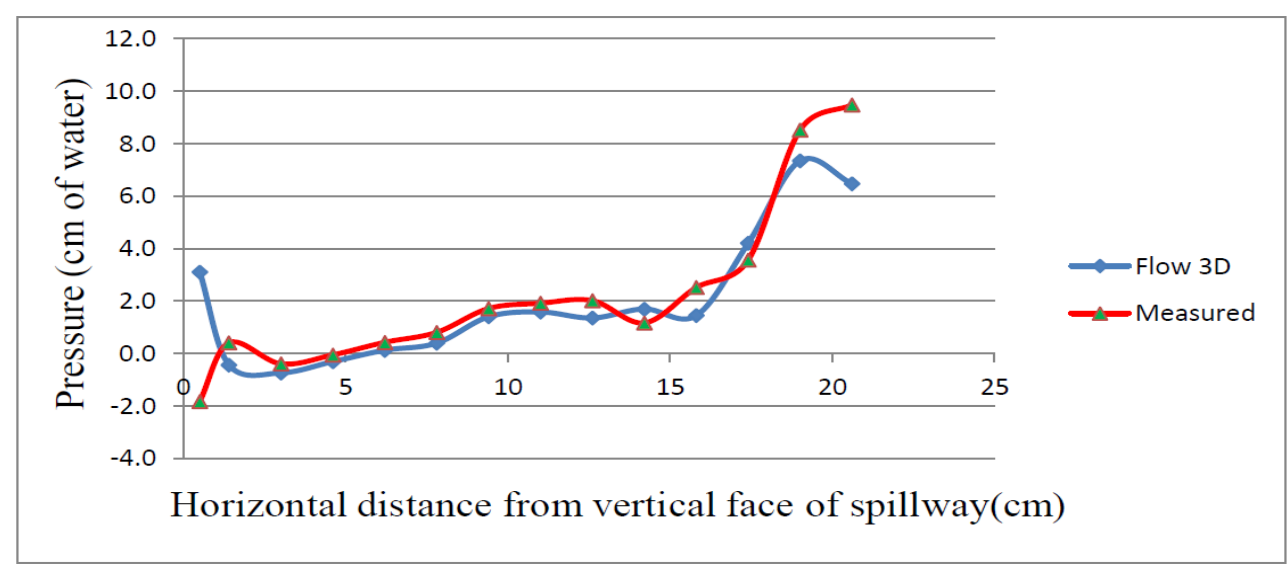

Fig. (5-a): Comparison between measured and computed values of pressure on model $(1)(\mathrm{P}=20 \mathrm{~cm}$ and $\mathrm{Hd}=5$ $\mathrm{cm}$ and $\mathrm{H} / \mathrm{H}_{\mathrm{d}}=1.2$ ).

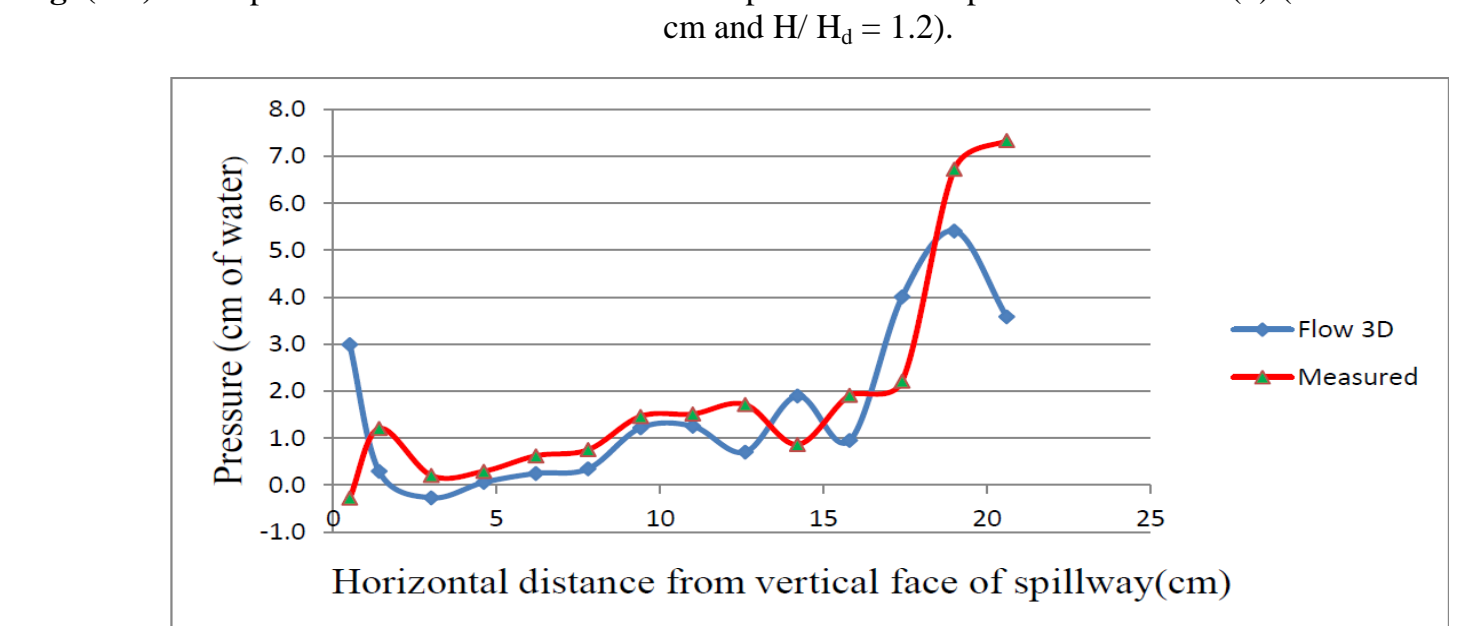

Fig. (5-b): Comparison between measured and computed values of pressure on model $(1)(\mathrm{P}=20 \mathrm{~cm}$ and $\mathrm{Hd}=5 \mathrm{~cm}$ and $\left.\mathrm{H} / \mathrm{H}_{\mathrm{d}}=1.0\right)$. $\mathrm{m}$ water surface and those at the toe region are attributed to high turbulence and air entrainment in the flow. Similar comparisons for models two and three are shown in Figs (6-a) to (7-e) indicating good agreements with little discrepancies at regions of crest and toe. The above comparisons for water surface profiles and pressure results are justified and acceptable logically and scientifically.

$$
\text { and } \left.\mathrm{H} / \mathrm{H}_{\mathrm{d}}=1.0\right) \text {. }
$$




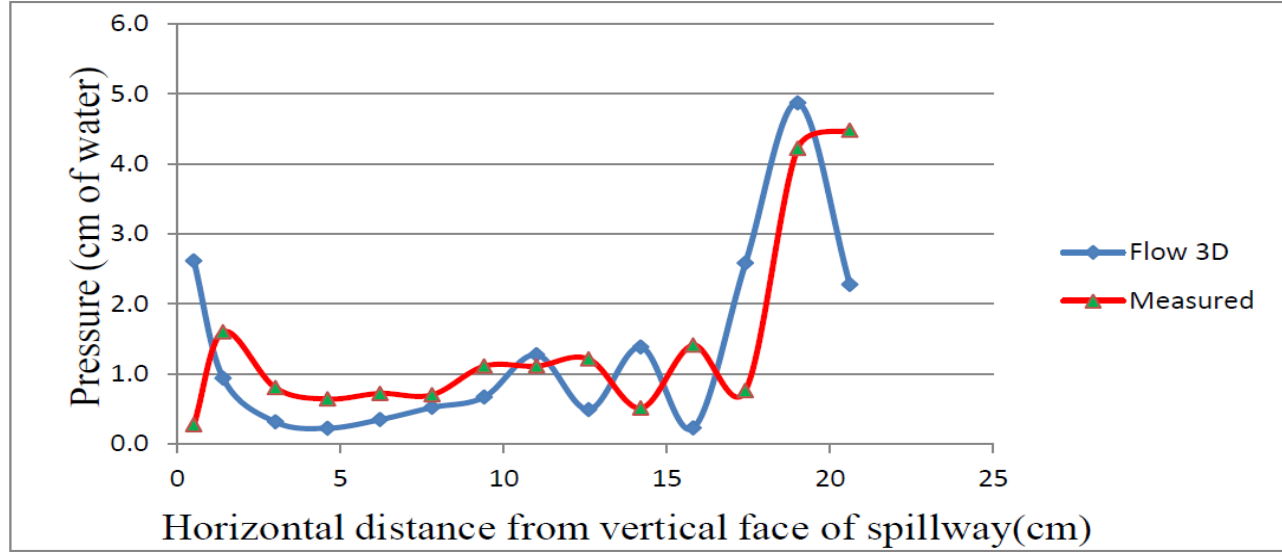

Fig. (5-c): Comparison between measured and computed values of pressure on model (1) $(\mathrm{P}=20 \mathrm{~cm}$ and $\mathrm{Hd}=5 \mathrm{~cm}$ and $\left.\mathrm{H} / \mathrm{H}_{\mathrm{d}}=0.75\right)$.

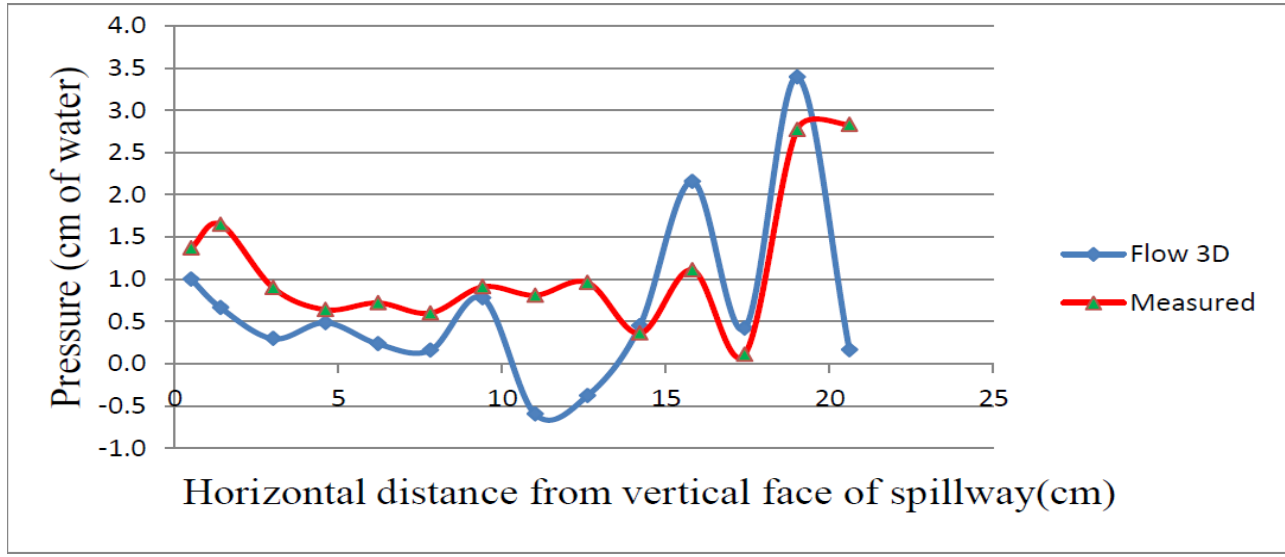

Fig. (5-d): Comparison between measured and computed values of pressure on model (1) $(\mathrm{P}=20 \mathrm{~cm}$ and $\mathrm{Hd}=5 \mathrm{~cm}$ and $\left.\mathrm{H} / \mathrm{H}_{\mathrm{d}}=0.5\right)$.

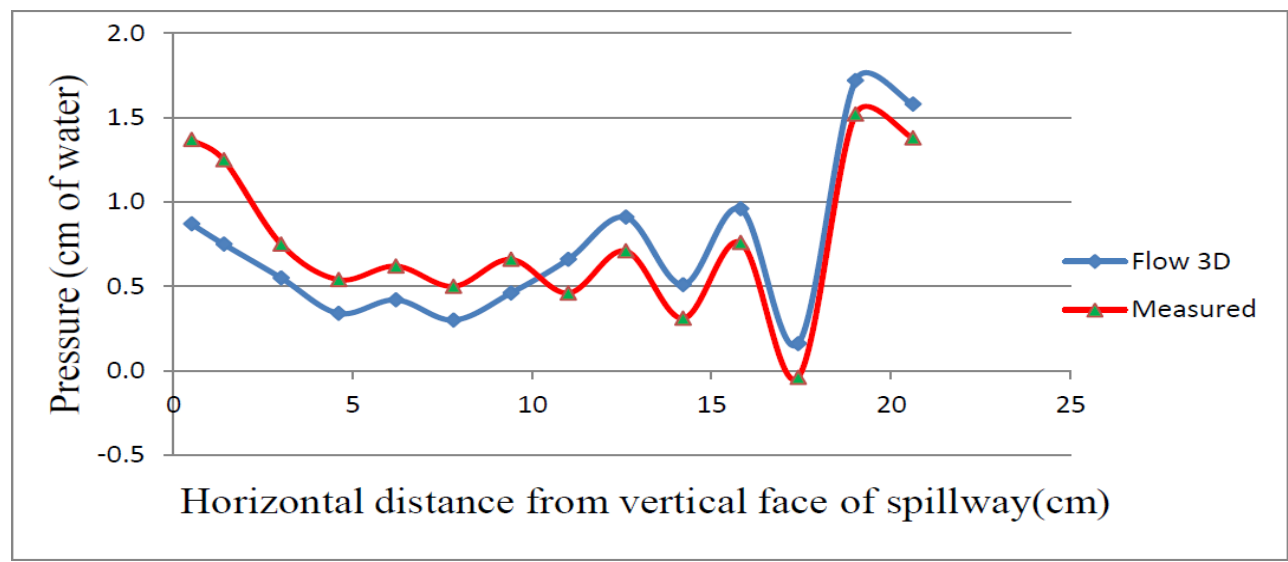

Fig. (5-e): Comparison between measured and computed values of pressure on model (1) $(\mathrm{P}=20 \mathrm{~cm}$ and $\mathrm{Hd}=5 \mathrm{~cm}$ and $\mathrm{H} / \mathrm{H}_{\mathrm{d}}=0.25$ ). 


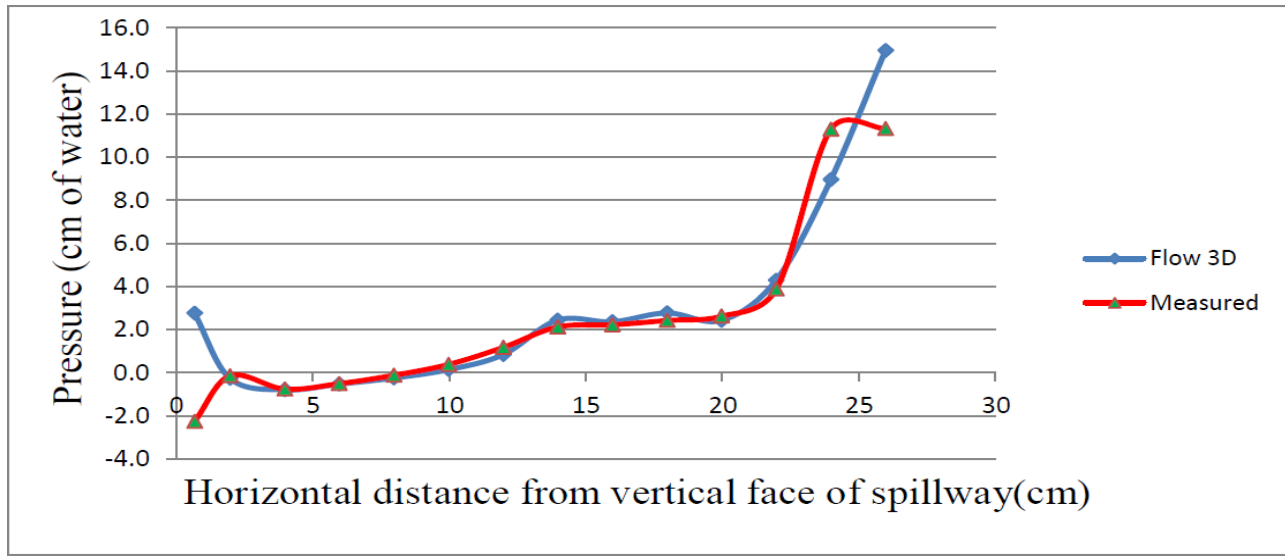

Fig. (6-a): Comparison between measured and computed values of pressure on model (2) $(\mathrm{P}=25 \mathrm{~cm}$ and $\mathrm{Hd}=7 \mathrm{~cm}$ and $\left.\mathrm{H} / \mathrm{H}_{\mathrm{d}}=1.2\right)$.

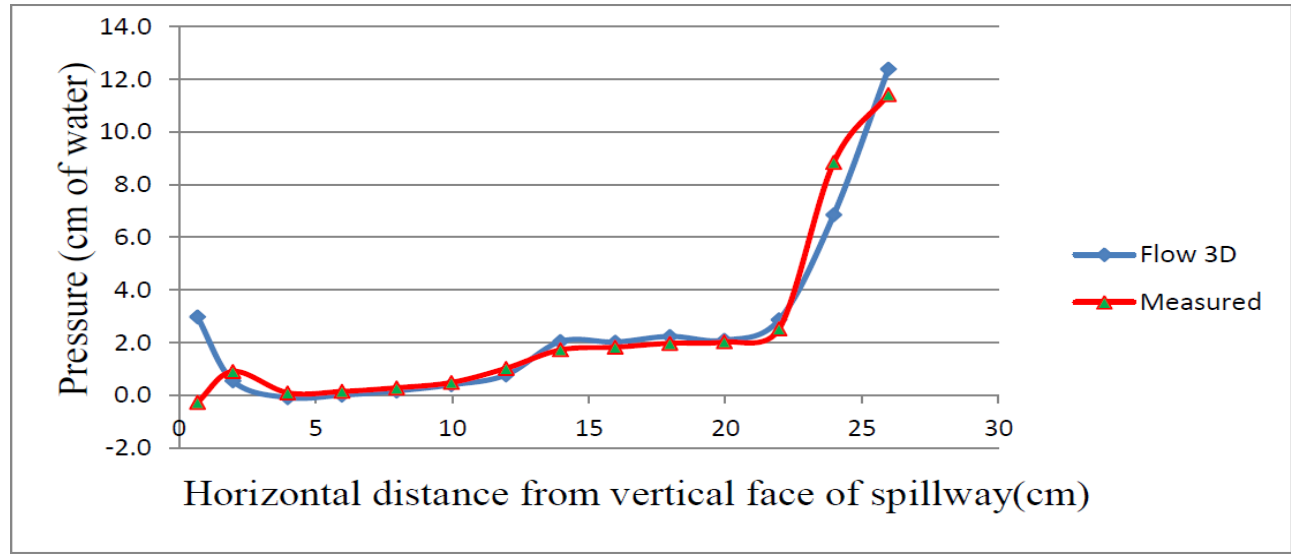

Fig. (6-b): Comparison between measured and computed values of pressure on model (2) $(\mathrm{P}=25 \mathrm{~cm}$ and $\mathrm{Hd}=7 \mathrm{~cm}$ and $\left.\mathrm{H} / \mathrm{H}_{\mathrm{d}}=1.0\right)$.

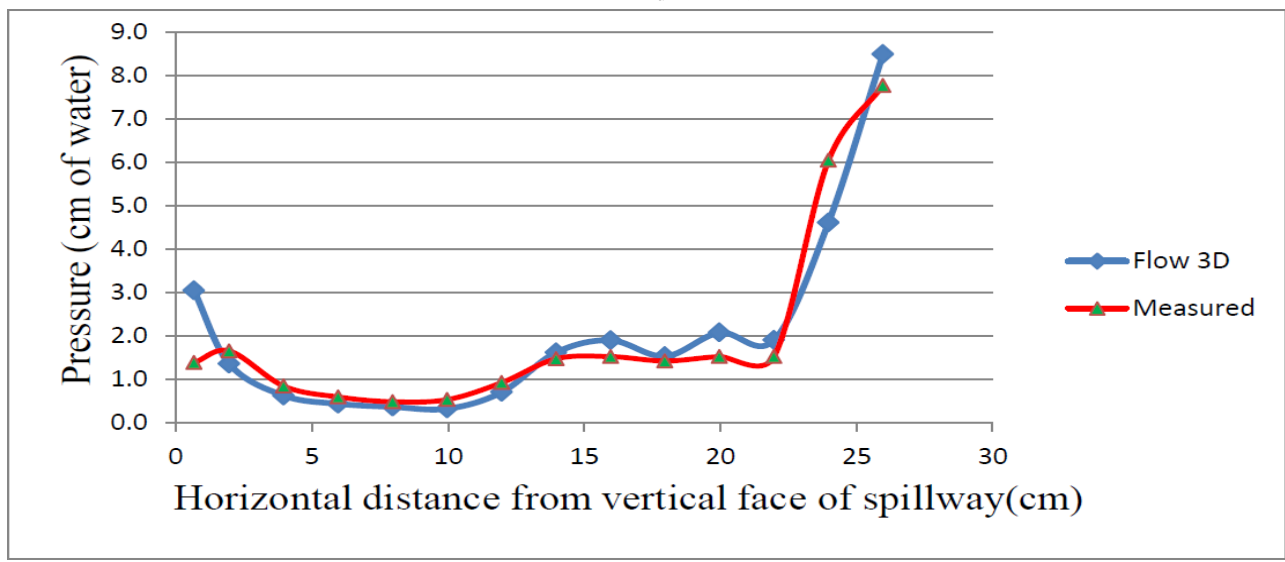

Fig. (6-c): Comparison between measured and computed values of pressure on model (2) $(\mathrm{P}=25 \mathrm{~cm}$ and $\mathrm{Hd}=7 \mathrm{~cm}$ and $\mathrm{H} / \mathrm{H}_{\mathrm{d}}=0.75$ ). 


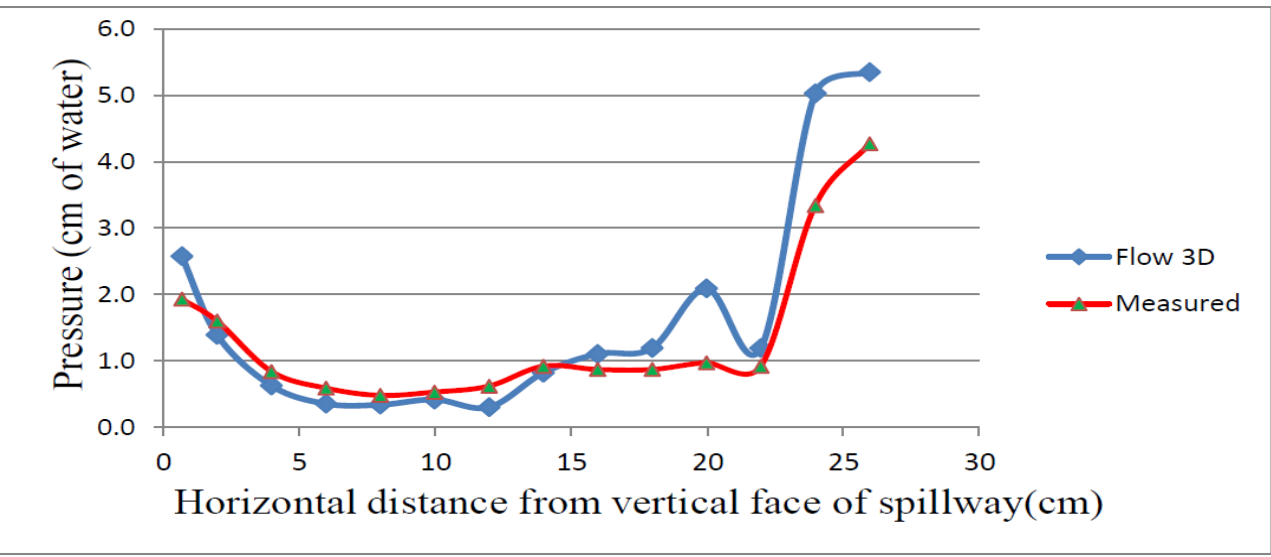

Fig. (6-d): Comparison between measured and computed values of pressure on model $(2)(\mathrm{P}=25 \mathrm{~cm}$ and $\mathrm{Hd}=7 \mathrm{~cm}$ and $\mathrm{H} / \mathrm{H}_{\mathrm{d}}=0.5$ ).

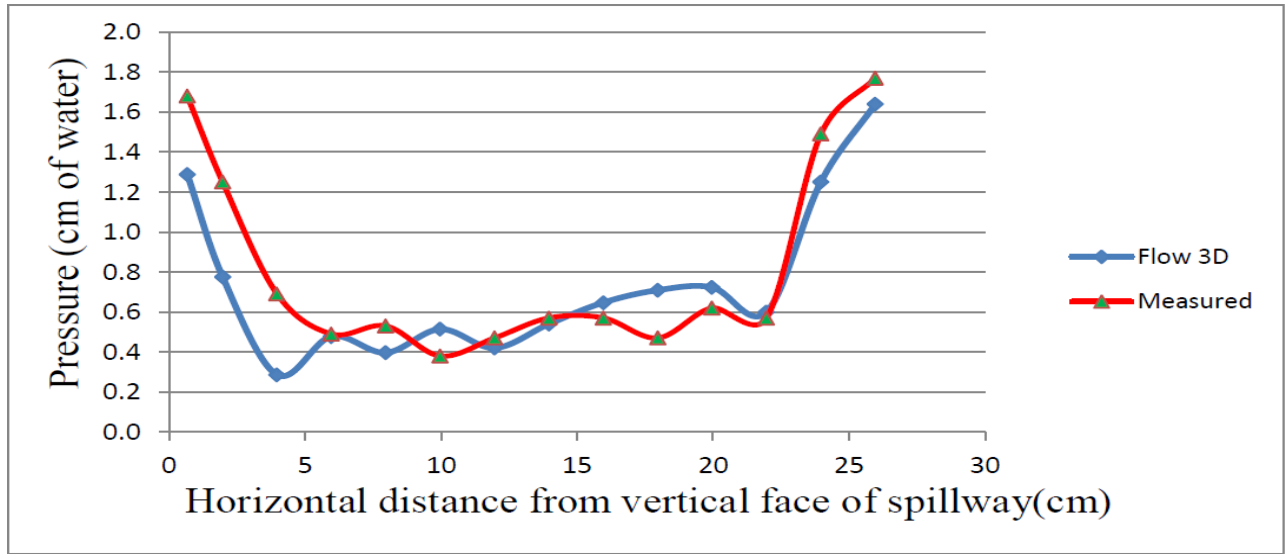

Fig. (6-e): Comparison between measured and computed values of pressure on model (2) $(\mathrm{P}=25 \mathrm{~cm}$ and $\mathrm{Hd}=7 \mathrm{~cm}$ and $\left.\mathrm{H} / \mathrm{H}_{\mathrm{d}}=0.25\right)$.

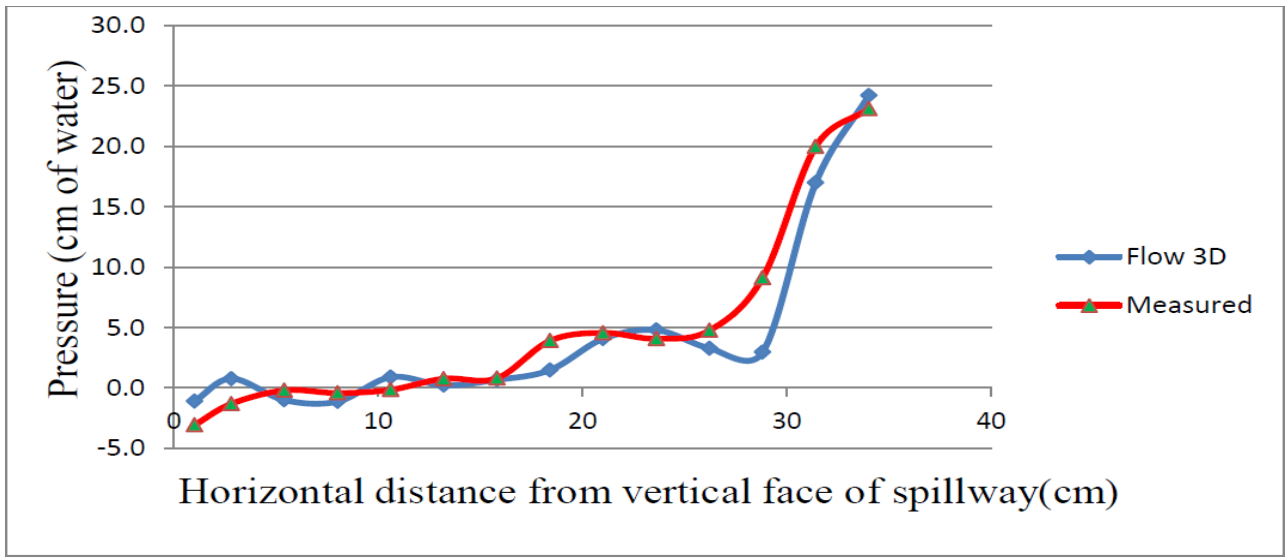

Fig. (7-a): Comparison between measured and computed values of pressure on model (3) $(\mathrm{P}=30 \mathrm{~cm}$ and $\mathrm{Hd}=10$ $\mathrm{cm}$ and $\mathrm{H} / \mathrm{H}_{\mathrm{d}}=1.2$ ). 


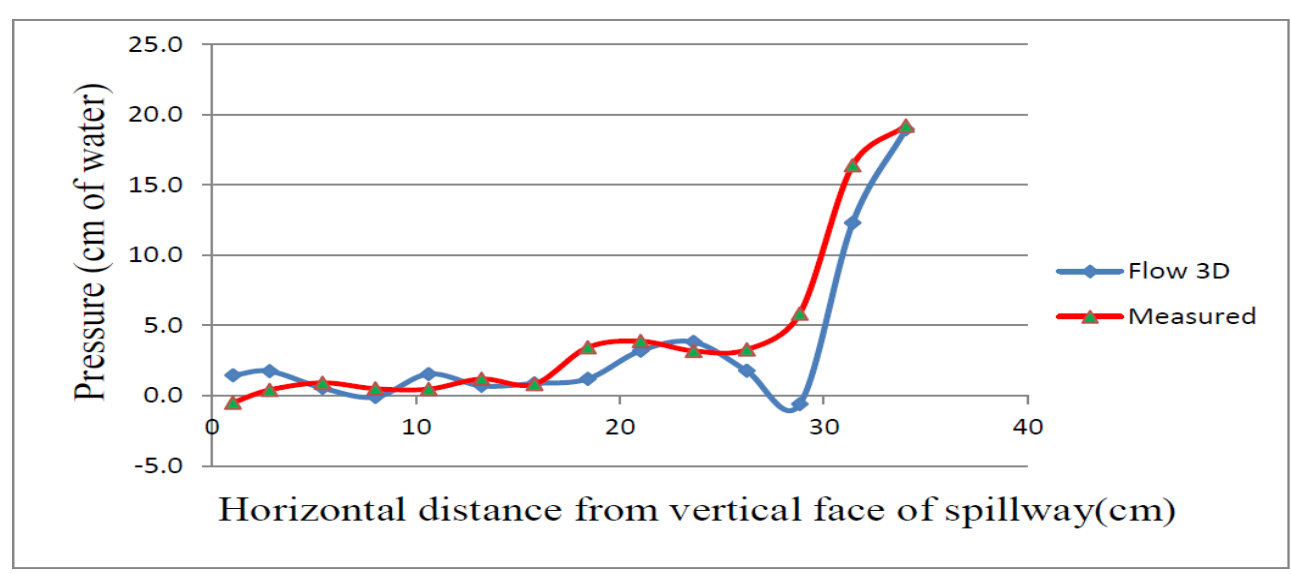

Fig. (7-b): Comparison between measured and computed values of pressure on model (3) $(\mathrm{P}=30 \mathrm{~cm}$ and $\mathrm{Hd}=10$ $\mathrm{cm}$ and $\left.\mathrm{H} / \mathrm{H}_{\mathrm{d}}=1.0\right)$.

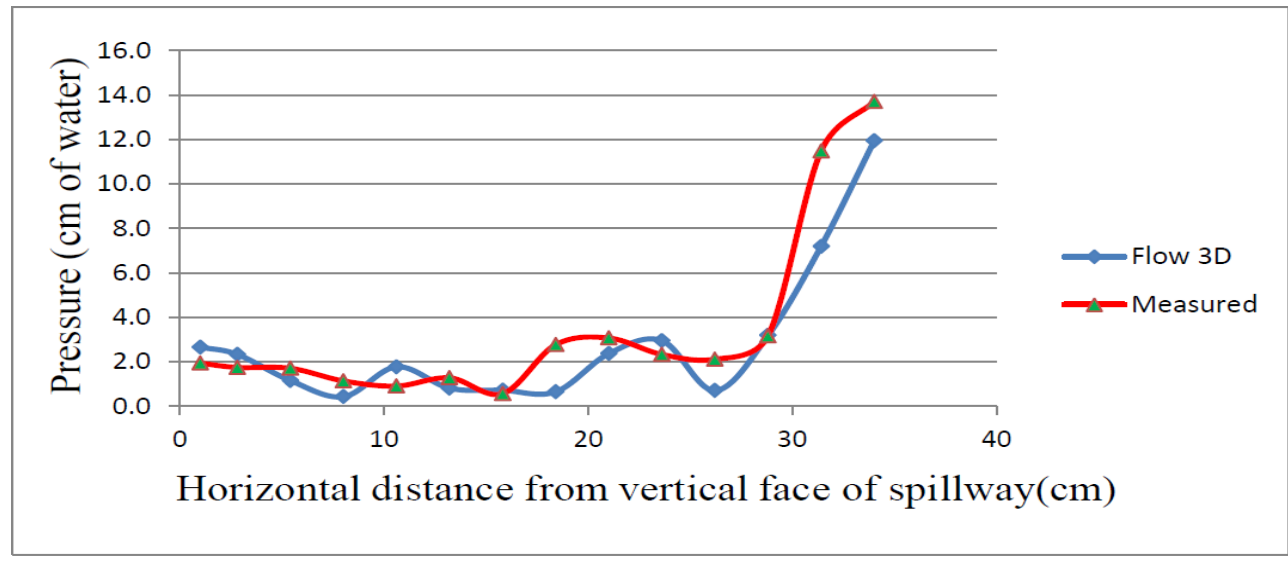

Fig. (7-c): Comparison between measured and computed values of pressure on model (3) $(\mathrm{P}=30 \mathrm{~cm}$ and $\mathrm{Hd}=10$ $\mathrm{cm}$ and $\left.\mathrm{H} / \mathrm{H}_{\mathrm{d}}=0.75\right)$.

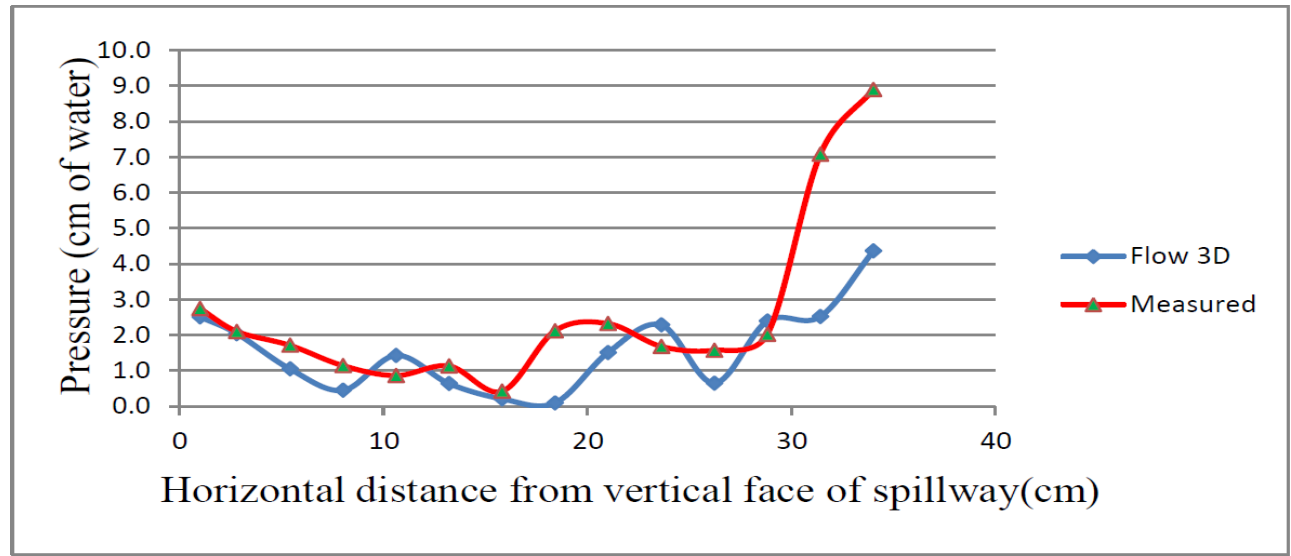

Fig. (7-d): Comparison between measured and computed values of pressure on model (3) $(\mathrm{P}=30 \mathrm{~cm}$ and $\mathrm{Hd}=10$ $\mathrm{cm}$ and $\left.\mathrm{H} / \mathrm{H}_{\mathrm{d}}=0.5\right)$. 


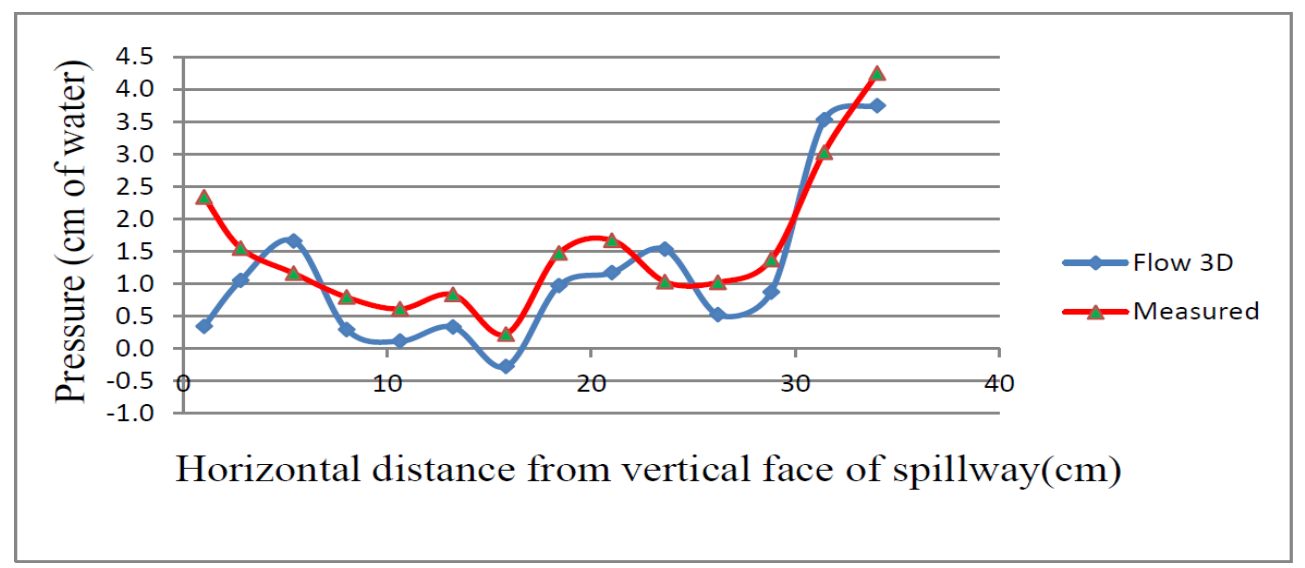

Fig. (7-e): Comparison between measured and computed values of pressure on model (3) $(\mathrm{P}=30 \mathrm{~cm}$ and $\mathrm{Hd}=10$ $\mathrm{cm}$ and $\left.\mathrm{H} / \mathrm{H}_{\mathrm{d}}=0.25\right)$.

\section{CONCLUSIONS}

The present study has been taken up as a contribution toward a better understanding of the water surface profile and pressure distribution along the surface of ogee-crested spillways. For this purpose, three models of ogee-crested spillway were fabricated and tested in a laboratory flume. A numerical model using (CFD, Flow-3D) was developed to analyze the three models numerically and to compare the numerical results with those of physical models. From this study, the following conclusions and findings can be summarized as:

1. Water surface profiles showed good agreements between the measured results of the physical models and those of the numerical models for the $\left(\mathrm{H} / \mathrm{H}_{\mathrm{d}}\right)$ ratios of $1.2,1,0.75,0.5$ and 0.25 despite little discrepancies not exceeding $7 \%$ at the region of toe of the spillway.

2. Some discrepancies were also observed from the comparisons between the results measured from the physical models and those of the numerical models for the pressure distributions along the center line of the spillway surface for the $\left(\mathrm{H} / \mathrm{H}_{\mathrm{d}}\right)$ ratios of $1.2,1,0.75,0.5$ and 0.25 . These discrepancies were found at the regions of crest and toe which could be attributed to the fluctuations in the upstream water surface and turbulence and air entrainment at the toe region. These comparisons are acceptable logically and scientifically.

3. The (CFD, Flow-3D) software is still developing and changing so that any validation against experimental results is only applicable to the specific case model, the specific program and solver version used.

\section{REFERENCES}

- Bhajantri, M.R., Eldho, T.I. and Deolalikar, P.B. (2006). "Hydrodynamic Modeling of Flow over a Spillway Using a Two Dimensional Finite Volume Based Numerical Model”, Sadhana, PP. 743-754

- Chatila, J. and Tabbara, M. (2004), "Computational Modeling of Flow over an Ogee Spillway", Computers and Structures; Vol 82; PP. 18051812.

- Gessler, D. (2005). "CFD Modeling of Spillway Performance", EWRI 2005: Impacts of Global Climate Change, Proceedings of the World Water and Environmental Resources Congress, Anchorage, Alaska. 15-19 May. Edited by R. Walton. American Society of Civil Engineers.

- Guo, Y., Wen, X., Wu, C. and Fang, D. (1998). "Numerical Modeling of Spillway Flow with Free Drop and Initially Unknown Discharge", Journal of Hydraulic Research, Vol.36, No. 5 PP.785-801.

- Harlow, F.H., and Welsh, J.E. (1965). "Numerical Calculation of Time-dependent Viscous Incompressible Flow of Fluid with Free Surface", Phy. Fluids, Vol. 8; PP. 2182-2189.

- Ho, D. and Donohoo, S. (2001)."'Investigation of Spillway Behavior under Increased Maximum Flood by Computational Fluid Dynamics Technique", Proceeding of 14th Australasian Fluid Mechanics Conference, Adelaide University, Adelaide, Australia, PP. 10-14.

- Ho, D., Boyes, K., Donohoo, S. and Cooper, B. (2003). "Numerical Flow Analysis for 
Spillways", 43rd ANCOLD Conference, Hobart, Tasmania, October 24-29.

- Ho, D., Cooper, B., Riddette, K. and Donohoo, S. (2006). "Application of Numerical Modeling to Spillways in Australia", Dams and Reservoirs, Societies and Environment in the 21st Century, Edited by Berga et al., Taylor and Francis Group, London.

- Irzooki, R. H., Mohammed, J. R. and Ameen, A. S. (2016). "Computational Fluid Dynamics Modeling of Flow over Stepped Spillways", Tikrit Journal of Engineering Sciences, Vol. 23, No. 3, PP. 1-11.

- Johnson, M., and Savage, B. (2006). "Physical and Numerical Comparison of Flow over Ogee Spillway in the Presence of Tail Water", Journal of Hydraulic Engineering, Vol. 132, No.12, ASCE, PP.1353-1357.

- Khatsuria, R. M. (2005). "Hydraulics of Spillways and Energy Dissipaters", Mercel Dekker, NY, USA

- Kim, S. D, Lee, H.J. and An, S.D. (2010) "Improvement of Hydraulic Stability for Spillway Using CFD Model", International Journal of the Physical Sciences Vol. 5, No.6, PP. 774-780.
- Kjellesvig, H.M. (1996). "Numerical Modeling of Flow over a Spillway." Hydro informatics '96, Balkema, Rotterdam.

- Launder, B.E., Morse, A., Rodi, W., Spalding D.B. (1972). "A Comparison of Performance of Six Turbulence Models", NASA Conf. on Free Shear Flows, Nat. Aeronautics Space Admin., Washington D.

- Olsen, N.R.B., Kjellesvig, H.M. (1998). "ThreeDimensional Numerical Flow Modeling for Estimation of Spillway Capacity", Journal of Hydraulic Resarch, Vol. 36, No.5, PP. 775-784.

- Savage, B., and Johnson, M. (2001), "Flow over Ogee Spillway: Physical and Numerical Model Case Study", Journal of Hydraulic Engineering, ASCE, Vol. 127, No.8, PP. 640-649.

- Song, C.C.S. and Zhou, F. (1999)."Simulation of Free Surface Flow over Spillway", Journal of Hydraulic Engineering, ASCE, Vol.125, No.9, PP.959-967.

- United States Army Corps of Engineers Waterways Experiment Station (USACE-WES) (1952). Corps of Engineers Hydraulic Design Criteria, Revised in Subsequent years. 